\title{
Reseña: Acordeones, cumbiamba y vallenato en el Magdalena Grande: Una historia cultural, económica y política, 1870-1960. Joaquín Viloria De La Hoz. Editorial Unimagdalena, 2018
}

\author{
Jaime Bonet \\ Director Centro de Estudios Económicos Regionales (CEER) \\ Banco de la República, Cartagena, Colombia \\ jbonetmo@banrep.gov.co
}

Sugerencia de citación: Bonet, J. (2019). Reseña. Acordeones, cumbiamba y vallenato en el Magdalena Grande: Una historia cultural, económica y política, 1870-

1960. tiempo\&economía, 6(1), 191-194, doi: 10.21789/24222704.1408

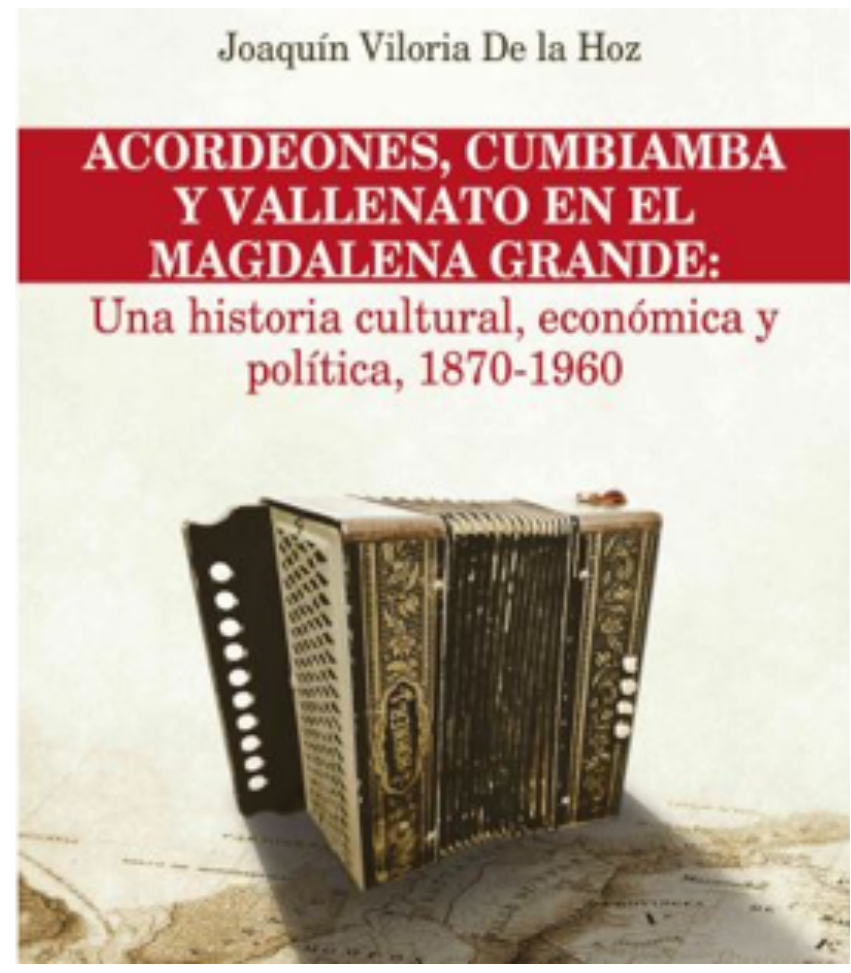


Existen varios trabajos que abordan la historia de la música vallenata, muchos de los cuales relatan la creación del Festival de la Leyenda Vallenata o narran las anécdotas que dieron origen a las canciones y que dan cuentan de las vivencias de los compositores y de los protagonistas de las letras. Este trabajo de Joaquín Viloria aborda esta historia con una rigurosidad de fuentes y considerando el contexto cultural, económico y político en el que este ritmo musical se consolidó como uno de los más importantes del país. Esta es una gran contribución a la cultura colombiana porque reconstruye parte de la historia del Magdalena Grande en el período 1870-1960.

El libro de Viloria deja varios mensajes clave para entender la evolución de la música de acordeón en el país. En primer lugar, la consolidación de este ritmo musical se dio siguiendo las bonanzas económicas que se registraron en el Magdalena Grande. Inicialmente Riohacha y sus alrededores vivieron una prosperidad comercial y una significativa dinámica demográfica entre 1840 y 1870, como resultado de la explotación del palo de tinte y el dividivi que era recogido por indígenas para ser exportados a Holanda, Inglaterra y Francia, principalmente. Viloria menciona que lo más probable es que la importante colonia de judíos de Curazao residentes en Riohacha a finales del siglo $x \mid x$, hayan sido quienes introdujeron los primeros acordeones por este puerto, debido a las conexiones que tenían con casas comerciales de Rotterdam, Ámsterdam, Londres y Nueva York.

La siguiente bonanza económica en el Magdalena Grande se dio en Ciénaga y sus alrededores, en la que comenzó a identificarse como la Zona Bananera, gracias al auge de las exportaciones de banano entre 1890 y 1930. La prosperidad económica atrajo a muchos migrantes extranjeros (italianos, franceses, españoles y árabes, principalmente) y nacionales (bolivarenses, santandereanos y guajiros). Con esta mezcla, Viloria argumenta que se fue formando la "cultura zonera", en donde el acordeón fue incorporado a las llamadas cumbiambas en la década de 1890.

El auge económico propiciaba también las parrandas, las fiestas, creando una efervescencia que atraía a muchos intérpretes provincianos del acordeón a ofrecer su arte en las cantinas, lo que ayudó a la divulgación de la música de acordeón por la región. Viloria menciona relatos que indican que algunos de los acordeoneros de provincia compraban instrumentos que luego vendían en los pueblos de sus territorios generalizando así la masificación del acordeón en el Magdalena Grande.

El tercer auge económico se presentó con el despegue de Valledupar. Esta ciudad se mantuvo aislada hasta la década de 1930, cuando llegó a la presidencia de la república Alfonso López Pumarejo, cuya madre era oriunda de esta ciudad. Este presidente impulsó las vías que permitieron la integración con Santa Marta y Riohacha. A finales de 1940 comenzó la siembra de algodón en esta provincia, que luego consolidó una bonanza económica sin precedentes en las décadas de 1950 y 1960. Como resultado, la que más tarde sería la capital del Cesar duplicó su población en la primera mitad del siglo xx. De esta forma, Valledupar se convirtió en el epicentro de la música de acordeón del Magdalena Grande a mediados del siglo xx.

En medio de este cambio en las tendencias económicas, Viloria muestra que se fueron dando las importaciones de los primeros acordeones a Colombia. El primer registro encontrado de ingresos del instrumento data de finales de la década de 1860. Aunque la información contiene solo el peso y no el número, el autor hace una estimación de la cantidad considerando 
el peso de los acordeones usadas en ese lapso de tiempo. Así se estimó que, en el año fiscal 1869-1870, Colombia importó 17 acordeones por las distintas aduanas del Caribe: once por Riohacha, cuatro por Sabanilla y dos por Cartagena. Luego, en el año transcurrido entre 1871 y 1872 se registró un incremento importante en las importaciones de acordeones. En este periodo ingresaron al país 291 instrumentos, 63\% a través de la aduana de Sabanilla y el resto por Cúcuta.

El acordeón se convirtió en un instrumento fundamental de los grupos musicales de finales del siglo xIx y comienzos del siglo xx. Las celebraciones que se realizaban eran llamadas cumbiambas. De hecho, los relatos de distintos viajeros que pasaron por el Caribe colombiano coinciden en mencionar la presencia de dichas cumbiambas en varios pueblos caribeños.

El autor indica que no era muy claro el nombre del ritmo musical que se interpretaba con el acordeón. Esa indefinición llevó a que en las décadas de los 1940 y 1950 se denominara como "porro", donde se incluían varios de los ritmos existentes como la cumbia, el bullerengue, el merengue, la puya y hasta el mismo porro. Con el tiempo, los ritmos fueron diferenciándose unos de otros y en especial la música de acordeón comenzó a marcar una diferencia frente a otros ritmos que se interpretaban en el Caribe colombiano.

Un hecho que destaca el autor es que el surgimiento de la música de acordeón en Colombia se dio en el momento en que la industria discográfica y la radiodifusión eran las fuerzas dominantes de la cultura musical del país. Esas tendencias contribuyeron a que la música campesina del Magdalena se convirtiera en música popular y se propagara rápidamente en el Caribe colombiano con el nombre de música vallenata.

De igual forma, se iniciaron festivales de música vallenata en diversos pueblos del Magdalena Grande como Fundación, El Retén, Pivijay, La Paz y Aracataca, entre otros. Uno de los concursos pioneros era organizado por el comerciante libanes Camilo George Chams en Fundación, con el fin de promover la venta de las radiolas y los discos de acetato en su negocio. El primero se realizó en 1950 y se prolongó hasta 1959, aunque no se tiene claridad sobre la periodicidad con la que se realizaba este evento.

Otro de los festivales del que se tiene referencia en la historia es el organizado en 1966 por sugerencia de Gabriel García Márquez en Aracataca. Después de varios años fuera del país, García Márquez le pidió a su amigo Rafael Escalona que le organizara una gran parranda con los principales intérpretes de acordeón. El escritor había conocido el vallenato durante su paso por La Paz (Cesar), cuando era vendedor de enciclopedias en la zona y su amigo Manuel Zapata Olivella prestaba el servicio médico rural obligatorio en esa población. Asistieron delegaciones de músicos de Valledupar, Santa Marta, Barranquilla, Cartagena, Ciénaga, Fundación, Pivijay y Aracataca principalmente.

Esta idea fue tomada por un grupo de vallenatos, los cuales, luego de la creación del departamento del Cesar, decidieron constituir el Festival de la Leyenda Vallenata, que, aprovechando la celebración de una tradición religiosa en Valledupar, escogería como rey vallenato al mejor intérprete de acordeón. De esta manera se consolida este género como uno de los más importantes y representativos del país.

La obra de Viloria es un relato ameno y con rigurosidad académica que aporta nuevos elementos a la historia de la música de acordeón en el país. Los lectores podrán entender los 
194 Reseña. Acordeones, cumbiamba y vallenato en el Magdalena Grande: Una historia cultural, económica y política, 1870-1960. Joaquín Viloria De La Hoz. Editorial Unimagdalena

doi: https://doi.org/10.21789/24222704.1408

orígenes y evolución de este género musical desde finales del siglo XIX hasta mediados del siglo XX. A su vez, el texto narra el contexto económico del Magdalena Grande en ese periodo, el cual es clave para comprender la consolidación de la música de acordeón en el Caribe colombiano. 